\title{
Süreç İyileștirme: Vasıflı Çelik Üretim Sektöründe Bir Uygulama
}

\author{
Tansu TÜRKAN*, Ali GÖRENER**
}

ÖZ

Teknolojinin gelişimi ve yaşam koşulların değişimi, müşteri taleplerini çeşitlendirmektedir. Birçok farklı seçeneğin, makul fiyat ve istenen zamanda karşılanmasını arzu eden müşterilere hizmet verilen küresel bir rekabet ortamı mevcuttur. Bu rekabet ortamında, yüksek kaliteli ve uygun fiyatlı ürünlerle müşteri talebine istenen sürede cevap verilebilmesi gerekmektedir. Belirtilen hususlar 1şı̆̆ında, işletmelerin süreçlerini sürekli olarak gözden geçirmeleri ve iyileştirme gereklilikleri karşımıza çıkmaktadır. Yapılan bu çalışmada ilk olarak, süreç kavramı ve süreç iyileştirme hakkında genel bilgiler verilmiștir. Uygulama kısmında ise ana hedef sektörü otomotiv yan sanayi olan ve tam zamanında üretim felsefesi ile çalışan müşterilere ürün tedarik eden, vasıflı çelik üretimi yapan bir firmada gerçekleştirilen süreç iyileştirme çalışmaları sunulmuştur. Çalışmada farklı süreç iyileştirme teknikleri (Kaizen, Neden-Sonuç Diyagramı, Poka-Yoke, 8D, Hata Türü ve Etkileri Analizi) bir arada kullanılmıştır.

Anahtar Kelimeler: Süreç İyileştirme, Vasıflı Çelik Üretimi, Otomotiv Endüstrisi

JEL Sınıflandırması: M-11, L-23

\section{Process Improvement: An Application in Special Steel Production Sector}

\begin{abstract}
Customer requests are increasingly varied with the changing of the living conditions and developing technology. In this point, customers want to be met the demands which are good quality and suitable price quickly. The trend in today's global competitive environment is to provide high quality, reasonably priced products and respond in the required time to customer demands. In this point, organizations should review their processes continuously and improve them. In this study begin with the general information about concept of process, process management and process improvement techniques. This paper continuous with an application in a steel production company which supplies product to the customers in the automotive industry that working with just in time philosophy. In this study different techniques for process improvement (Kaizen, Cause and Effect Diagram, PokaYoke, 8D, Failure Modes and Effects Analysis) were used in combination.
\end{abstract}

Keywords: Process Improvement, Special Steel Manufacturing, Automotive Industry

JEL Classification: M-11, L-23

\footnotetext{
* Öğrenci, İstanbul Ticaret Üniversitesi, SBE, tansuturkan@ gmail.com

*** Doç. Dr., İstanbul Ticaret Üniversitesi, İşletme Fakültesi, İşletme Bölümü, agorener@ticaret.edu.tr
} 


\section{GİRIŞ}

İmal edilen ürünler hakkındaki tüm inisiyatifin üreticide olduğu, "Siyah olduğu sürece her renge sahip olabilirsiniz" anlayışının var olduğu dönemlerden müşterinin talep ettiği ve bu talep doğrultusunda üretimin yapıldığı döneme geçilmiştir. Bu bağlamda kuruluşlar müşterinin sesini dinlemek, ona en iyi şekilde hizmet ve ürün sunmak zorundadırlar. Rekabette bugün gelinen noktada değişimi göremeyen, müşterinin sesini duyamayan kuruluşlar istedikleri hedeflere ulaşmada zorluk yaşamaktadırlar. Bu noktada karşımıza süreç yönetimi kavramı çıkmaktadır. Süreç, önceden belirlenen amaçlar doğrultusunda girdileri çıktılara dönüştüren faaliyetler serisine denmektedir. Süreç yönetiminin amacı ise müşteri memnuniyetini sağlamak ve kaynakların daha doğru yerlerde kullanılarak katma değerli ürünlerin ortaya çıkmasını sağlamaktır.

Süreç içerisinde katma değer sağlamayan faaliyetlerin tespit edilmesi ve sistemden uzaklaştırılması, kaynakların doğru yerde kullanılabilmesi için oldukça önemlidir. Çünkü bu faaliyetler müşteri tarafindan değer görmemekle birlikte zaman kaybı ve israfa neden olmaktadır. Bu sebeple işletmeler süreçlerini sürekli iyileştirme felsefesi ile devamlı izlemeli, gözlemlemeli ve kontrol etmelidirler. İşletmeler süreçlerini iyileştirmek için bir takım araçlara başvurabilmektedirler. Kuruluşlar sürekli iyileştirme anlayışını çalışanlarına da benimsetmelidirler. Süreç iyileştirme tekniklerinin nasıl uygulanacağına ve ne gibi yararlar sağlayacağına dair çalışanlara bilgilendirmeler yapılması, eğitimler verilmesi gerekir.

Bu çalışmanın amacı, imalat sektöründe faaliyet gösteren bir firmada süreç iyileştirme teknikleri kullanılarak, zaman tasarrufu, maliyetlerde düşme vb. gibi avantajların elde edilmesine yönelik düzenlemelerin yapılmasıdır. Çalışmanın ilk bölümünde süreç kavramı, sürecin özellikleri, süreç yönetiminin amacı, faydaları ve uygulama nedenlerinden bahsedilmiştir. İkinci bölümde süreç iyileştirme ve çalışmada kullanılan tekniklerden bahsedilmiştir. Uygulama kısmında ise çelik parça üretimi yapan bir firmada gerçekleştirilen çalışmalar aktarılmıştır. Çalışma devam etmekte olup, firmada sağlanan mevcut kazanımlar aktarılmıştır. Uygulamalar çeşitlendirilerek devam ettirilmektedir.

\section{SÜREÇ VE SÜREÇ YÖNETIMİ}

Süreç kavramı, girdileri çıktılara dönüştüren faaliyetler olarak ifade etmektedir. Süreç tanımına ilk olarak 1978'de 'American Heritage' sözlügünde yer verilmiştir. Süreç kavramı 'bir son veya bir sonuç meydana getiren bir dizi eylem, değişiklik veya işlev' olarak tanımlanmıştır (Oğuz, 2011:9). Bu tanımda yalnızca çıktı ve faaliyetler üzerinde durulmuştur. Zamanla istek ve taleplerin çeşitlenmesi neticesinde bu tanım yetersiz kalmıştır. Yapılan tanımlar ile birlikte süreç kavramını irdelediğimizde;

- Girdisi ve çıktısı olmayan bir süreç olamaz.

- Girdiyi çıktıya dönüştüren birden fazla faaliyet olması gereklidir. Herhangi bir süreç tek faaliyetten oluşuyorsa süreç olarak tanımlamak mümkün değildir.

- Her sürecin müşterisi vardır. Bu müşteriler iç veya dış müşteri olabilir.

- Her sürecin sahibi vardır.

Süreç iyileştirme çalışmaları ilk etapta beklenen etkiyi ortaya çıkaramayabilir. Bunu birçok nedene bağlayabiliriz. Yeni yönteme hızlıca adapte olamama, çalışanların yeniliklere karşı direnç göstermesi gibi hususlar ortaya çıkabilir. Problemleri önlemenin temel unsurları; üst yönetim desteğinin çalışanlar tarafından hissedilmesi ve çalışanlara kazanımlarında ifade edileceği yöntemlere ilişkin bilgilerin aktarılmasıdır. Süreç iyileştirme faaliyetlerinin başarılı 
olması ile işletme iç ve dış müşteri memnuniyetini arttırabilmekte ve rekabet avantajı sağlayabilmektedir. Çalışanlara bu kapsamda farkındalık kazandırılmalıdır (İnce vd., 2013:245).

\section{SÜREC İYILESTIRME TEKNIKLERİ}

Süreç iyileştirme anlayışı, işletme süreçlerine odaklanılarak analizler yapılır, süreçlerin daha iyi yönetilebilmesi için alternatif yöntemler araştırılır. Bu çalışmalar neticesinde sınırlı kaynaklar daha doğru yerlerde kullanılarak israflar azaltılır. İsrafın azaltılması ile maliyetler düşer. Çalışanların performansında artış sağlanır ve böylece daha kaliteli çıktılar oluşur. Süreç iyileştirmede en önemli noktalardan biri de sistematik olmasıdır. İşletmenin başarılı olabilmesi için kabul edilebilir seviyede iyileştirmeler yapması ve bunları sürekli iyileştirme yaklaşımı ile kontrol etmesi gereklidir (Arslan vd., 2015:124-125).

Süreç iyileştirme konusunda uygulanmakta olan çok sayıda teknik vardır. Organizasyonların süreçleri birbirinden farklılık gösterdiği için kullandıkları iyileştirme teknikleri birbirinden farklı olabilmektedir. Farklılık aynı zamanda iyileștirme yapmak istedikleri alana veya sürece göre de değişiklik gösterebilir. En ideal teknikler şeklinde sınıflandırabileceğimiz bir küme yoktur (Ertuğrul, 2006:155). Temel teknikler şu şekilde sıralanabilir: 5S, Önce ve sonra kaizen uygulaması, Kobetsu kaizen, Neden-sonuç diyagramı, 8D, Poke-Yoke, FMEA (Failure Modes and Effect Analysis-Hata Türleri ve Etkileri Analizi), Kontrol kartları ve grafikleri, Histogramlar, Dağılım diyagramı, Pareto analizi, Zaman etüdü, Beyin firtınası, Nominal grup tekniği, Çetele tablosu, Akış şeması, Ağaç diyagramı, Ok diyagramı, Kıyaslama, Güç alanı analizi, Kalite fonksiyon göçerimi ve Altı sigma. Çalışma da kullanılan bazı teknikler izleyen bölümlerde kısaca açıklanmıştır.

\section{1. Önce ve Sonra Kaizen Uygulaması}

Çoğunlukla çalışanların veya danışmanların önerileri ile gelen, sonuçlanması kısa süren iyileştirmeleri ifade etmektedir. Hataya yol açan, maliyeti arttıran veya işlem süresini arttıran bir olay veya aşama söz konusudur. Bu kapsamda çözüm için öneriler değerlendirilir. Uygulanan çözüm, öncesi ve sonrasını gösteren, kazanımları belirten bir form ile ifade edilir. Önce ve sonra kaizen uygulamas1;

- Moral ve motivasyonu arttıran,

- Karmaşık olmadığı için herkes tarafından kolayca anlaşılabilen,

- Çalışanları düşünmeye yönelten,

- Daha akıllıca çalışılmasını sağlayan,

- Önerilerin sistematik hale gelmesine yardımcı olan faydalı bir tekniktir (Çetinay, 2016:20)

İyileştirme çalışmalarının en küçük yapı taşı olan önce sonra kaizenleri, her alanda ve bir çok kişi tarafindan uygulanabilecek temel bir iyileştirme tekniğidir. Ortalama 8 günde tamamlanan çalışmalardaki en önemli hususlardan birisi, aksiyon almak için onay mekanizmalarında fazla zaman kaybetmeme gerekliliğidir (Öztürk, 2016:3).

\subsection{Neden-Sonuç Diyagramı}

Neden-sonuç diyagramı; bir sonucun ortaya çıkış nedenlerinin ifade edilmesine ilişkin bir iyileştirme aracıdır. Kalite öncülerinden Dr. Kaoru Ishikawa tarafından geliştirildiğinden, Ishikawa diyagramı olarak da bilinmektedir (Gitlow vd., 2005:358). 


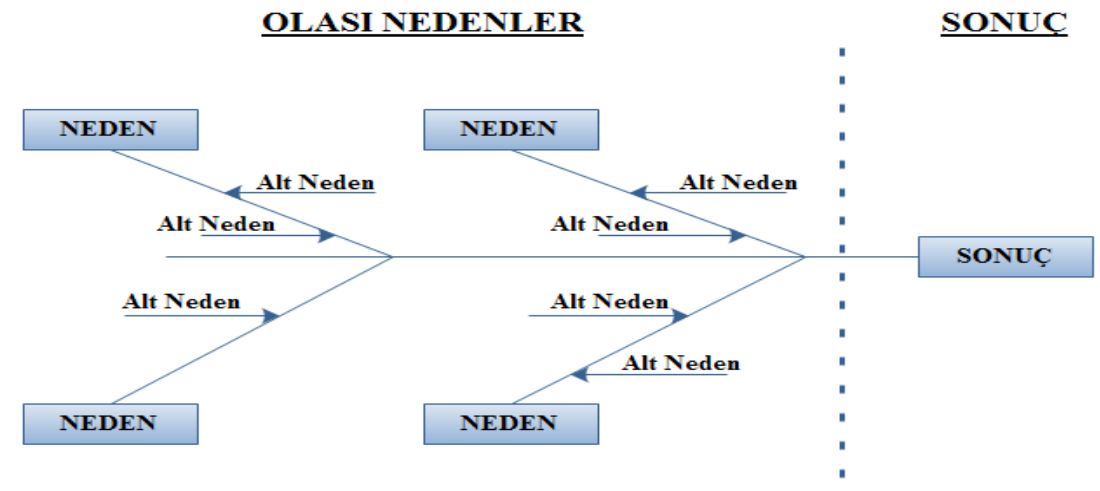

Şekil 1: Neden- Sonuç Diyagramı

Kaynak: (Gitlow vd., 2005: 358).

Neden-sonuç diyagramları; probleme yol açan ana nedenlerin tanımlanması, analiz edilmesi ve ne yapılacağına karar verilmesi süreçlerinin düzenlenmesinde kullanılır (Ertuğrul, 2006:183). Neden-sonuç diyagramı, süreçlerde meydana gelen problemleri çözümlemek üzere, problemin nedenlerinin ayrıntılarını grafiksel olarak açıklamayı sağlayan bir yaklaşımdır (Işı̆̆ıçok, 2012:89). Diyagram genel olarak, sağ köşede sonucun ifade edildiği, bu kısmın solunda ise nedenlerin açıklandığı iki bölümden oluşur. Şekil 1'de neden-sonuç diyagramının genel yapısı görülmektedir.

\subsection{Poka-Yoke (Hatadan Sakınma) Analizi}

Poka-yoke yöntemi ilk olarak Shigeo Shingo tarafından 1986 yılında kullanılmıştır. Poka; dalgınlık, görülmeyen hata gibi anlamlara gelirken yoke ise; önlemek, azaltmak anlamlarına gelir. Bu yöntem insan hatalarından kaynaklanan problemlerin süreçten elimine edilmesi, uzaklaştırılması için tasarlanmıştır. Özellikle manuel yapılan işlerde insanlar hata yapmaya eğilimlidir ve bunun sonucunda ortaya çıkan hatalarda kişiler suçlanabilmektedir. Poka-yoke anlayışında sorunun esas nedeni kişilerde değildir. Hataların ortaya çıkmasına sebep olan durum analiz edilir ve kaynağında önlenmeye çalışılır. Yöntemin etkin olabilmesi için süreçte yaşanabilecek hataların belirlenmiş olması gerekir (Treurnicht vd., 2011:214).

Poka yoke yöntemi kontrol etmek, uyarmak ve sistemi komple kapatmak veya durdurmak üzerine kuruludur. Burada kullanılan elemanlar ise uyarı amaçlı kullanılan 1şıklı sistemler, kontrol listeleri, sensörler, sonlandırıcı şalterlerdir (Bulut, 2012:44). Bu yöntem hata bulma ve hatayı önleme olarak ikiye ayrılır. Hata olmadan önce, oluşabilecek hataları analiz edip önlemler alarak hatanın oluşmasına engel olur. Diğer taraftan oluşan hatanın bir daha tekrarlanmaması için de düzenleyici faaliyetlerin yapılmasını gerekli kılar (Bozdemir ve Orhan, 2011:468-469).

\subsection{D Problem Çözme Yöntemi}

İlk olarak Amerikan ordusunda 1980 y1lında kullanılmıştır, sonrasında Ford bu yöntemi otomotiv sektörüne kazandırmıștır (Yılmazer, 2016:4). İşletmelerde kişiler her ne kadar işlerini dikkatli yapsalar da bazı zamanlarda ve durumlarda hataların önüne geçilemez. Özellikle manuel işlemlerin fazla olduğu işletmelerde bu gibi durumlar kaçınılmazdır. Bunun neticesinde de müşteri şikâyetleri ortaya çıkar. Ortaya çıkan şikâyetlerin kökten çözümünü sağlayabilmek için 
de 8 disiplin olarak adlandırılan 8D problem çözme yöntemi kullanılabilmektedir. Amacı problemlerin esas sebeplerinin ne olduğunu bularak tamamıyla ortadan kaldırmak, aynı sorun ile bir daha karşılaşmamaktır.

Kobetsu kaizen yönteminde müşteri özel bir yöntem kullanılmasını istemiyorsa 8D problem çözme basamakları takip edilebilir. Diğer yöntemlere göre daha karmaşık ve zorlayıcıdır. Bahsi geçen 8 disiplin şu şekilde özetlenmiş̧tir (Grace, 2016:3):

D0- Planlama: Problemin çözümü için ön koşullar belirlenir.

D1-Ekip oluşturmak: Süreci bilen kişilerden ekip kurulmalıdır.

D2- Problemi belirlemek ve tanımlamak: 5N1K (ne, nerede, ne zaman, nas1, neden, kim) yöntemi ile problemin kök nedenine inilmelidir.

D3- Acil aksiyon planlama, yürütme ve aksiyonlar alma: Sorun ortaya çıkmadan önleyici aksiyonlar tanımlamalı ve yürütülmelidir.

D4- Kök neden belirleme: Problemin neden dolayı meydana geldiğini açıklamak ve bulmak en önemli aşamadır. Beyin firtınası ile pareto analizi, neden-sonuç diyagramı gibi tekniklerle nedenler belirlenebilir (Buyruk, 2014:1).

D5-Aksiyonu seçmek: Bir önceki adımda bulunan esas nedeni ortadan kaldıracak en iyi düzenleyici faaliyeti/ aksiyonu seçmek.

D6-Düzeltici faaliyet uygulama ve geçerli kılma: En iyi aksiyon belirlenir ve uygulanmaya başlanır.

D7-Önleyici önlemler almak: Tüm benzer hataların tekrarını önlemek için yönetim sistemi, operasyonel sistemler, uygulamalar ve prosedürler geliştirilmelidir.

D8- Ekibi tebrik etme: Kolektif şekilde çalışmış ve sonuçları raporlamış olan ekibin takdir edilmesi veya ödüllendirilmesi aşamasıdır.

Özetle 8D yöntemi; mevcutta var olan ya da olma ihtimali olan problemlerin çözümü için kullanılır. İlk aşamada "8D Uygunsuzluk Bildirim Formu" açılır. Bu formda yer almış problemler için ilgili kişi tarafından analizler hazırlanır. Analizlerde kök nedene inecek şekilde çeşitli bilgiler toplanır. $\mathrm{Bu}$ değerlendirmeler, belli zaman aralıklarında yapılan toplantılara katılan birimlerin fikrine sunulur. Farklı birimlerden oluşan ekip kurularak hatanın oluşmasına neden olan sorunlar tespit edilip çözüm üretilir (Solak ve Korkut, 2015:112).

\subsection{HTEA Tekniği}

Hata türü ve etkileri analizi (HTEA) ürün geliştirilmesinde, servis, sistem ve süreçlerin iyileştirilmesinde, hata türlerinin belirlenmesi ve sınıflandırılması için kullanılan bir yöntemdir (Eleren, 2007:4). HTEA, ürün veya sistemdeki hataların nedenlerini ve etkilerini analiz etmek için kullanılabilecek sistematik bir yaklaşımdır (Yüksel, 2010:256).

HTEA tekniğinde, hata türleri risk düzeylerine göre sıralanmakta, en yüksek önceliğe sahip hata türlerinden başlanarak önlemler belirlenmektedir. Sisteme ilişkin iyileştirme çerçevesi adım adım oluşturulmaktadır. HTEA uygulama aşamaları şu şekilde ifade edilebilir (Kahraman ve Demirer, 2010:58):

- Başlangıç çalışmaları,

- Tehlike kaynaklarının ve tehlikelerin belirlenmesi

- Olası hata etkilerinin, nedenlerinin ve mevcut kontrollerin belirlenmesi 
- Olasılık, şiddet, tespit ve RÖS değerlerinin belirlenmesi,

- RÖS' e göre hataların sıralanması, alınacak önlemlerin belirlenmesi

- Öngörülen önlemlerin hayata geçirilmesinin ardından ROS değerlerinin yeniden hesaplanmas1

Yöntemin özünde, risk öncelik sayılarının (RÖS) belirlenmesi vardır. Bu sayılar aşağıdaki şekilde hesaplanmaktadır:

Risk Öncelik Sayısı (RÖS) = Oluşma Olasılığ x Şiddet x Saptanabilirlik

Bu denklemde, "Oluşma olasılığı" hatanın sıklık düzeyini; "Şiddet" hatanın önem derecesini; "Hataların Saptanabilmesi" veya "Tespit" ise söz konusu hatanın kullanıc1ya ulaşmadan fark edilebilme seviyesini ifade etmektedir. RÖS değerinin doğru saptanması, uygulamanın başarısı açısından oldukça önemlidir. Bu tür risk analizi tekniklerinde sayısal ve yeterli veri, başarıyı arttıran bir unsurdur. Yeterli verinin bulunmadığı, ya da verilerin güvenilir olmadığı durumlarda olasılık, şiddet ve tespit değerleri uzman görüşüne başvurularak ifade edilmektedir (Kumru ve Kumru, 2010:176).

Olasılık, şiddet ve saptanabilirlik değerlerine ilişkin ölçekler Tablo 1'de bütünleşik halde sunulmuştur (Kahraman ve Demirer, 2010:60).

Tablo 1: Hataların Ortaya Çıkma Olasılığı ve Puanı

\begin{tabular}{|l|c|l|c|l|c|}
\hline Hatanın Olasılığı & Puan & Şiddet Etkisi & Puan & $\begin{array}{l}\text { Saptanabilirlik } \\
\text { Olasılı̆̆ }\end{array}$ & Puan \\
\hline $1 / 2$ 'den fazla & 10 & Uyarısız gelen yüksek tehlike & 10 & Fark Edilemez & 10 \\
\hline $1 / 3$ & 9 & Uyarısız gelen tehlike & 9 & Çok az & 9 \\
\hline $1 / 8$ & 8 & Çok yüksek & 8 & Az & 8 \\
\hline $1 / 20$ & 7 & Yüksek & 7 & Çok düşük & 7 \\
\hline $1 / 80$ & 6 & Orta & 6 & Düşük & 6 \\
\hline $1 / 400$ & 5 & Düşük & 5 & Orta & 5 \\
\hline $1 / 2000$ & 4 & Çok düşük & 4 & Yüksek Ortalama & 4 \\
\hline $1 / 15000$ & 3 & Küçük & 3 & Yüksek & 3 \\
\hline $1 / 150000$ & 2 & Çok küçük & 1 & Çok yüksek & 2 \\
\hline $1 / 150000$ 'den düşük & 1 & Yok & & Kesin & 1 \\
\hline
\end{tabular}

Kaynak: (Kahraman ve Demirer, 2010:60).

RÖS hesaplaması için ifade edilen üç faktörün çarpılmasıyla elde edilen sayının büyüklüğü, değerlendirme için en önemli kriterdir. Tablo 2'de risk öncelik sayısına ilişkin değerlendirme ölçeği verilmiştir (Pillay ve Wang, 2003:78; Kahraman ve Demirer, 2010).

Tablo 2: RÖS Değerlendirme Ölçeği

\begin{tabular}{cc}
\hline RÖS Değeri & Önlem Durumu \\
\hline RÖS $<40$ & Önlem almaya gerek yok. \\
$40 \leq$ RÖS $\leq 100$ & Önlem alınabilir. \\
RÖS $>100$ & Kesinlikle önlem alınması gereklidir. \\
\hline
\end{tabular}

Kaynak: (Kahraman ve Demirer, 2010: 61).

Belirtilen tekniklerle ilgili literatürde de çeşitli çalışmalar mevcuttur. Yücel (2007) gerçekleştirmiş olduğu çalışmasında emek yoğun bir üretim olduğunu ifade ettiği konfeksiyon 
sektörünü ele almıştır. Dikim hatalarını giderilmesi problemini HTEA ile irdeleyerek, iyileştirme önerileri sunmuştur. Ookalkar vd. (2009) sağlık alanında, hemodiyaliz süreçlerinin iyileştirmesi amacıyla HTEA tekniğini uygulamışlardır. Sawhney vd. (2009) ise yalın sistemlerin güvenilirliğinin arttırılması HTEA tekniğini uygulamışlardır.

Chiozza ve Pozetti (2009) yapmış oldukları çalışmada hasta güvenliği çerçevesinde medikal hatalara ilişkin risk değerlendirmesi yapmışlardır. Özellikle laboratuvar süreçlerini irdeleyen araştırmacılar HTEA tekniğini kullanmışlardır. Bozdemir ve Orhan (2011) çalışmalarında kaizen ve poka-yoke tekniklerine odaklanmışlardır. Sürekli iyileştirme felsefenin amacından ve yararlarından bahsetmişlerdir. Özellikle maliyetler üzerine etkisini araştırmış olup, Türk otomotiv sektöründe uygulanabilirliğini incelenmişlerdir. Saurin vd. (2012), poka-yoke araçlarının değerlendirilmesi için bir çerçeve metodoloji geliştirmişlerdir. En iyi uygulamaları baz alarak 15 farklı özellik kapsamında analizi gerçekleştirmişlerdir. Feili vd. (2013) jeotermal tesislerde risk analizi kapsamında HTEA yöntemini kullanmışlardır. Tespit ettikleri farklı risk öncelik sayısı değerleri için, komponentler bazında bakım, yenileme veya izleme gibi aksiyonlar önermişlerdir.

İnce vd. (2013) çalışmalarında süreç iyileştirme kavramı üzerine yoğunlaşmış olup, iyileştirme çalışmalarının getirilerinden ve neden yapılması gerektiğinden bahsetmişlerdir. Uygulamayı Sivas Numune Hastanesinde gerçekleştirmişlerdir. Çalışmada iyileştirme tekniklerinden kontrol tabloları, pareto analizi, neden-sonuç diyagramı ve akış şeması kullanılmışırı. Çalışmanın getirileri maliyet, zaman, teknik, kalite ve müşteri memnuniyeti boyutlarında ele alınmış ve değerlendirilmiştir. Özçelik ve Cinoğlu (2013) süreç iyileştirme kapsamında imalat yapan bir firmada konektör üretimini incelemişlerdir. Yapmış oldukları çalışmada neden-sonuç diyagramı, kaizen, poka-yoke, iş standartlaştırma yöntemlerini kullanarak hata oranlarını azaltmışlardır.

Tuzkaya ve Aksu (2013) ise, çalışmalarında bir imalat tesisinde stok yönetim sürecini incelemişlerdir. Mevcut durum analizleri ile stokun fazla olduğu anlaşılmıştır. Kullanılan süreç iyileştirme teknikleriyle bu problemlerin sebepleri ortaya çıkarılmıştır. Yararlanılan teknikler ise akış şeması ve balık kılçığıdır. Daha sonra yapılan hesaplamalar ile de optimum stok seviyesi belirlenmiş̧ir. Zerenler ve Karaboğa (2014) çalışmalarında müşteri memnuniyetinin sağlanmasında hata ve kusurların azaltılmasını amaçlayan poka-yoke tekniğine değinmişlerdir. İmalat sektöründe gerçekleştirdikleri uygulamaları anlatan araştırmacılar, tekniğin faydalarından bahsetmişlerdir. Pekin ve Çil (2015) ise otomotiv sektörüne kauçuk tedarik eden bir firmada aktif olarak uygulanan poka-yoke uygulamasını açıklamışlardır. Yapılan poka-yoke iyileştirmeleri ile çalışan kaynaklı problemlerin çoğunun ortadan kalktığını ve kalitesizlik oranının azalması ile firma için önemli katkılar sağlandığına değinmişlerdir. Özdağoğlu ve Rebiş (2016) çalışmalarında, PVC film üreten bir firmada çevrim süresini azaltmak için yapmış oldukları kaizen uygulamasını ve yalın üretim sistemine katkısını aktarmışlardır. Kang vd. ise (2017) yapmış oldukları çalışmada rüzgar türbinleri için risk değerlendirmesi yapmışlardır. Analizde HTEA yöntemini kullanmışlardır. Yapmış olduğumuz bu çalışmanın ise, vasıflı çelik üretimi özelinde süreç iyileştirme odaklı bir çalışmaya rastlanılmamış olması nedeniyle literatüre katkı sağlayacağı öngörülmektedir.

\section{UYGULAMA}

Çalışmanın bu bölümünde, ifade edilen tekniklerin imalat yapan bir firmada uygulanmasına ilişkin örnekler açıklanmıştır. Temelleri 1968 yılında atılan firma, Türkiye'nin lider vasıflı çelik ve parlak çelik üreticisidir. Firma 2015 yılında Türkiye'nin en büyük 500 şirketi arasında yer almıştır. Ayrıca aynı yıl ilk 1000 ihracatçı firmalar listesinde de yer almıştır. Bugün dünyanın 5 kıtasında 65 ülkede yaklaşık 8000 müşterisine hizmet vermektedir. Yaklaşık 
300 beyaz yaka, 400 mavi yaka çalışanı bulunmaktadır. Firma faaliyetlerini 3 ana dalda gerçekleştirmektedir. Bunlar:

Vasıflı Çelik Sıcak Hadde Üretimi: 300000 ton/yıl haddeleme kapasiteli Türkiye'de sürekli hizmet veren en modern tesis olan haddehanede, vakumlu döküm kütüklerden yuvarlak ve altı köşe sıcak olarak haddelenen ürünler üretilmektedir. Alaşımlı malzemelerin de ürün gamı içerisinde yer aldığı çelikler, sıcak hadde sonrası tamamlama hatlarında iç hata ve yüzey çatlak kontrollerinden geçirilerek \%100 çatlak kontrollü olarak da kullanıma sunulmaktadır.

Parlak Çelik Üretimi: 250000 ton/y1l parlak çelik işleme kapasiteli Soğuk İşlem Merkezi'nde kabuk soyma, taşlama, kumlama, soğuk çekme, kangal çekme, pah kırma ve çatlak kontrolü gibi çeşitli soğuk süreçler gerçekleştirilmekte, tamamlama hatları ile soğuk çekim kangallar ve soğuk çekim çubuklar, taşlanmış miller ve kabuk soyma miller müşteri talepleri doğrultusunda çatlak kontrollü olarak da sunulmaktadır.

Vasıflı Çelik ve Dikişsiz Boru Satış ve Dağıtımı: Vasıflı çelik sıcak hadde ve parlak çelik üretimlerinin yanı sıra dünyanın önemli üreticilerinden tedarik ettiği dövme çelik ve dikişsiz çelik boru satışını yapan firma; otomotiv, makine imalat, denizcilik, savunma, tarım makinaları ve beyaz eşya sanayi başta olmak üzere Türkiye'nin sanayileşmiş yedi şehrinde on farkl1 lokasyonda hizmet vermekte ve birçok ülkeye hammadde tedarik etmektedir.

İşletmede gerçekleştirilmiş olan iyileştirmeler firma yönetiminin talebi üzerine yapılmış olup, problemlerin çözümü için hangi araçların kullanılacağına araştırmacılar tarafından literatür incelemesi sonucu karar verilmiştir.

\section{1. Önce ve Sonra Kaizen Çalışmaları}

\subsubsection{Tamamlama Hattı Pah Kırma Süreci İyileştirme Çalışmaları}

İlk iyileştirme tamamlama hattında gerçekleştirilmiştir. Müş̧eri talebi üzerine tamamlama hattına gelen malzemeler yine müşteri talebine göre farklı işlemlerden geçirilebilmektedir. Bu hatta genel itibari ile üretimin yapıldığı üç farklı makine vardır. Müşteri, malzemenin çatlak kontrol testine tabi tutulmasını isterse malzemeler "sıcak hadde doğrultma ve sıcak hadde çatlak kontrol makinesinden" geçirilir. İş akışı özetle şu şekildedir: Malzemeler ilk önce "sıcak hadde doğrultma" makinesinde doğrultulur. Daha sonra uçlarına pah kırma işlemi yapılır. En son aşamada da yüzey hata ve iç hata kontrolünden geçirilir. Pah kırma işlemi oldukça önem arz etmektedir. Gelen hammaddelerin uçlarında çapak dediğimiz sivri yapılar oluşabilmektedir. Pah kırma işlemi ile bu çapaklar tıraş işlemi ile yok edilmektedir. Eğer pah kırma yapılmazsa çatlak kontrol makinesinin içinde yer alan seramik problara çapaklar zarar vermektedir ve bu problar oldukça maliyetli aparatlardır.

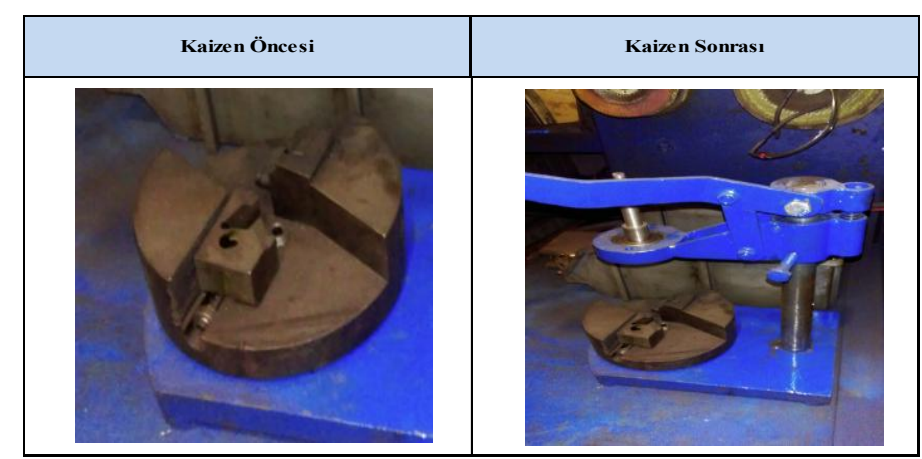

Şekil 2: Tamamlama Hattı Pah Kırma Süreci İyileştirme Çalışması 
Öncelikle seramik probların üst üste çatlaması üzerine incelemeler yapılmıştır. İncelemeye ilk olarak makineden çıkan malzemelerden başlanmıştır. Yapılan gözlemlerde malzemenin uçlarında çapak izlerine rastlanılmıştır. Bunun neticesinde pah kırma sürecinde problem olduğu anlaşılarak süreç izlenmiştir. Bu gözlemler sonucunda, pah kırma aparatının ayarlanmasının manuel yapılmasının ana sorun olduğu anlaşılmıştır. Çalışanların zorlandığı bu süreçte, ayarlama düzgün yapılamadığı için malzemeler çapaklı olarak makineye girmekte ve probların kırılmasına sebep olmaktadır. Ayarlamalar göz kararı ve kumpas kullanılarak yapılmaktadir.

Pah ayarının daha rahat yapılabilmesi için Şekil 2'de olduğu gibi bir aparat geliştirilmiştir. Aparat kılavuz görevi görmektedir. Bu aparat yardımıyla hem hızlı hem daha kolay pah ayarı yapılabilmektedir. $\mathrm{Bu}$ sayede çapaklar giderilerek probların kırılması engellenmiştir. Zamandan ve maliyetten tasarruf sağlayarak müşteri memnuniyetini arttırıcı iyileştirme yapılmıştır. Ayar kolaylığı ve kırılmanın engellenmesi ile işletmenin problemi giderilmiş, ayrıca bir performans kriteri konularak takip gerçekleştirilmemiştir.

\subsubsection{Paketleme Sürecine Yönelik İyileştirme Çalışması}

Tamamlama hattındaki makinelerden bir diğeri de "İkinci sıcak hadde doğrultma makinesidir". Müşteriden gelen talep, pah kırmasız doğrultma işlemi ise, malzemeler bu makinede üretime alınabilmektedir. Önceki dönemlerde bu makinede üretilip müşteriye giden malzemelerde çok sayıda şikâyet alınmıştır. Şikâyetlerin hepsi paketlemenin düzgün yapılamamasından dolayı gelmiştir. Şekil 3 'te birinci görselde olduğu gibi öncesinde paketleme işlemi oldukça düzensiz yapılmaktaydı. Bunun üzerine hattın sonuna tamponlama aparatı konulmuştur. Operatör hareketli konveyörler sayesinde malzemeleri ileri geri hareket ettirerek, malzemeleri bu aparata yaslamaktadır ve paketleme işlemi Şekil 3'teki ikinci görselde olduğu gibi düzgün şekilde yapılmaktadır. Bu yöntemle müşteri memnuniyeti arttırılarak kaliteli çıktı eldesi sağlanmıştır.

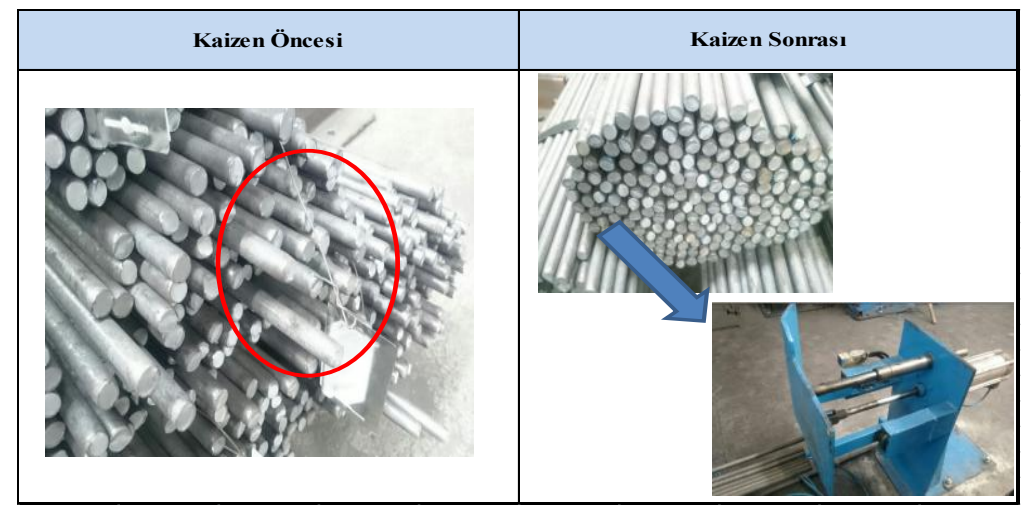

Şekil 3: Tamamlama Hattı İkinci Makine Tamponlanma Süreci İyileştirme Çalışması

\subsection{3. Çizik Oluşumunu Önleme Çalışması}

Tamamlama hattında malzemeler makineden çıtıktan sonra paketleme alanına gelmektedir. Malzemeler hareketli konveyörler sayesinde paketlemenin yapılacağı alana gelerek, $70 \mathrm{~cm}$ yükseklikten düşürülmektedir. Özellikle 70-100 çap aralığındaki malzemeler bu yükseklikten bırakıldıkları zaman çelik rölelerin bağlı olduğu miller kırılarak duruşların yaşanmasına sebep olmaktadır. Ayrıca malzemenin yüzeyinde de çizikler söz konusu olmaktadır. 
Mevcut durumu giderebilmek için, satın alma birimiyle ortak çalışmalar sonucu roleler 20 mm kalınlığında kauçuk kaplanarak mil üzerine gelen yükün kauçuk sayesinde absorbe edilmesi sağlanmıştır. Bu sayede $70 \mathrm{~cm}$ yükseklikten düşen malzemeler, rölelerin bağlı olduğu millerin hasar almasına neden olmamaktadır. Bu sebepten dolayı yaşanan duruşlar ortadan kaldırılmıştır. Bunun yanı sıra malzemeler yumuşak bir alana düştüğü için çiziklerin oluşması engellenmiştir.
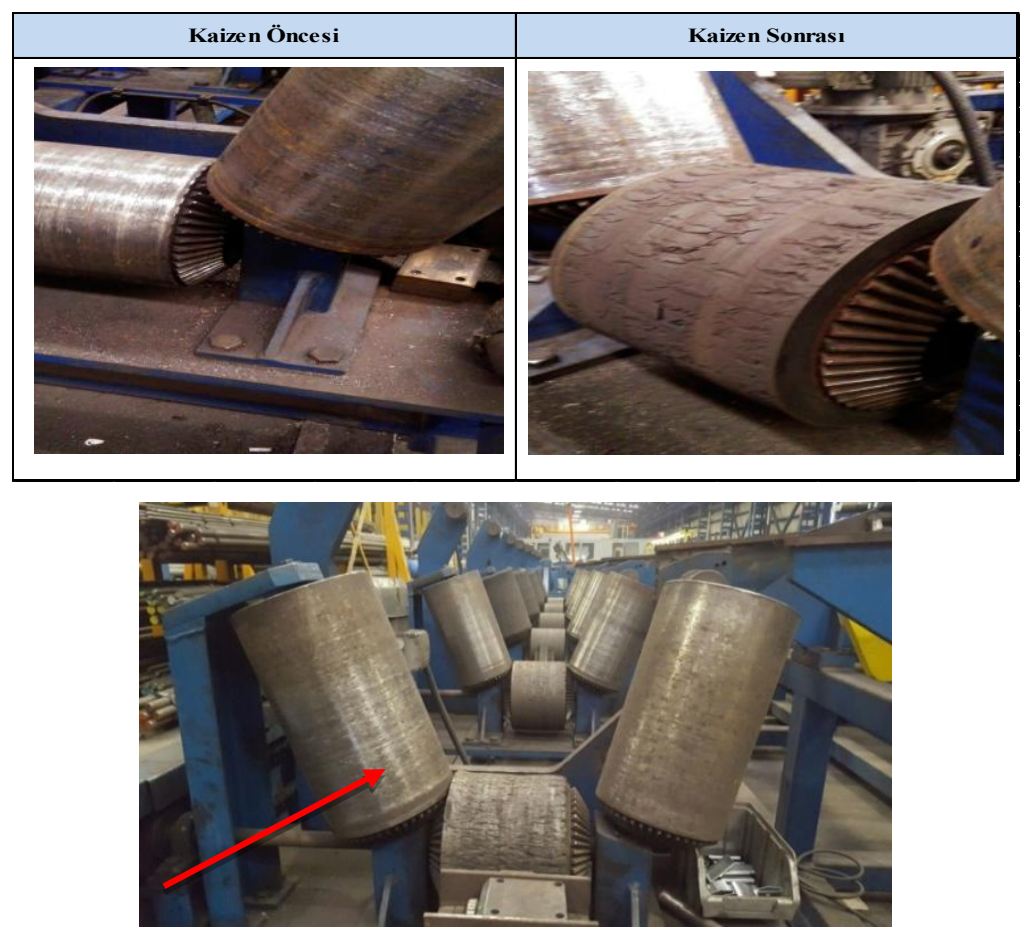

Şekil 4: Kauçuk Kaplanan Röleler

\subsection{Poka-Yoke Uygulamaları}

\subsubsection{Tamamlama Hattındaki İyileştirmeler}

Malzemeler, sıcak hadde çatlak kontrol makinesinden geçerken yüzey kontrol aşamasında çatlak tespit edilirse, sorunlu bölge kırmızı ile boyanmaktadır. Bu alan daha sonra taşlanmak üzere, malzeme kenara alınmaktadır. Hatalı olan kısım toleransları karşıladığı sürece taşlanarak çatlak giderilmeye çalışılır. Malzemenin taşlandığı alan Şekil 5'teki soldaki görselde gösterilen yerde yapılmaktadır.

Üretimi tamamlanan malzemeler sevk edilmeden önce kalite kontrolü yapılmaktadır. Kalite kontrol aşamasında, taşlandıktan sonra nihai ürün rafina alınan malzemelerde iki problem görülmektedir. Problemlerden biri taşlama istenen toleransın dışında yapılmış olması, diğeri de taşlama işlemi düzgün yapılamadığı için malzeme üzerinde hala çatlaklar, katlama izleri, tufal batması vb. izlerin mevcut olmasıdır. Yapılan gözlemler sonucunda, oldukça dikkat gerektiren taşlama işleminin yapıldığ 1 alanın ergonomik çalışma koşullarını tam olarak sağlamadığı görülmüştür. Taşlama oldukça dikkat gerektiren bir iştir. Gözle kontrol yapıllyor olması nedeniyle, kaynaklı bölgenin aydınlatması yeterli seviyede olmak zorundadır. Bu alandaki aydınlatmanın yeterli olmamasından dolayı çalışanlar hatalı bölgeleri tam tespit edememekte veya fazla taşlama yapmaktadırlar. Belirtilen sebeplerden dolayı malzemeler kusurlu kabul edilebilmektedir. 


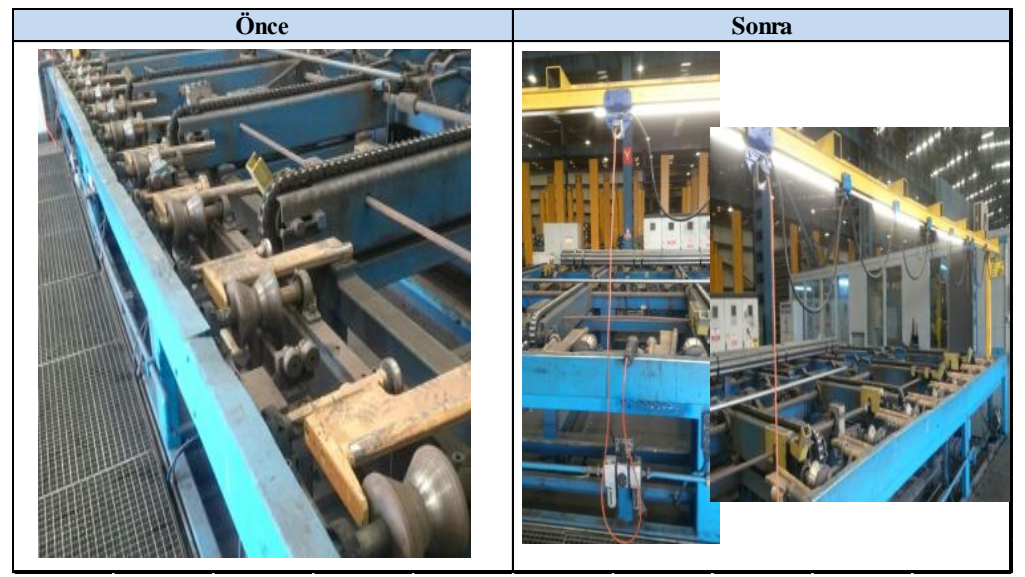

Şekil 5: Tamamlama Hattı Taşlama Süreci Poka-Yoke Uygulaması

Bu alanda Şekil 5’teki sağdaki görselde olduğu gibi led ışıklandırma yapılarak 500 lux 1şıklandırma sınırına ulaştırılmıştır. Böylece çalışanların hataları daha rahat görebilmesi sağlanmıştır. Aynı zamanda taşlama işlemi için kullanılan taş motorunun, balanser ile kullanımı sağlanarak cihaz istenen yere taşınabilir hale gelmiştir. Hammaddeden kaynaklı taşlamaya ayrılan malzemelerin miktarı çok olduğu zaman, işlem için ayrılan alanı doldurmaktadır. Taşlanacak malzemenin miktarı arttıkça kapasite yetersizliği söz konusu olmaktadır. Balanser sistemi sayesinde cihaz istenen yere uzatılarak ekstra alan oluşturulup, taşlama işlemi daha kolay hale getirilmiş, duruşların süresi azaltılmıştır.

\subsubsection{Sıcak Hadde Üretim Süreci İyileştirmesi}

Tamamlama hattına gelen hammaddelerin üretildiği sıcak hadde, sürekli bir hattır. Hat üzerinde tek bir yerde yaşanan hata tüm süreci durdurabilmektedir. Hata giderilip hat tekrardan çalıştırılmaya başladığında ise özellikle paketleme tarafında hattın çalışıp çalışmadığ çalışanlar tarafından anlaşılamamaktadır. Bu durum iş kazalarının oluşabilmesi açısından çok büyük risk teşkil etmektedir. Büyük iş kazalarına sebebiyet vermeden önleyici bir faaliyet düşünülerek, Şekil 6'da görüldüğü gibi hattın çalışıp durduğunu gösteren 1şıklı uyarıcılar takılmıştır. Bunun için trafik lambalarında kullanılan kırmızı, yeşil, sarı renkleri seçilmiştir. Bu sayede, belirtilen nedenden dolayı oluşması muhtemel büyük iş kazalarının önüne geçilmiştir.

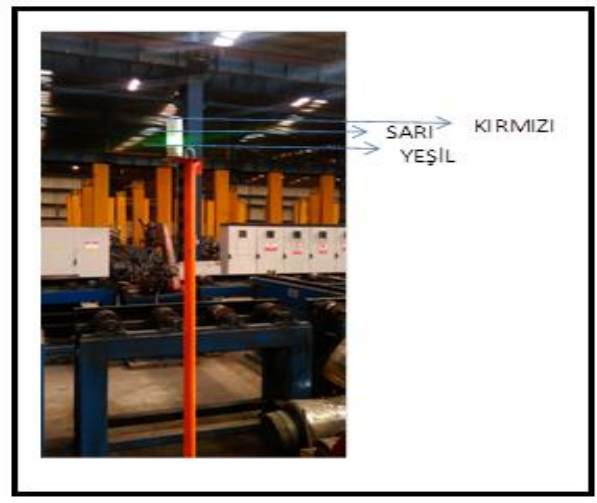

Şekil 6: Sıcak Hadde Üretim Süreci 


\subsection{D Uygulaması}

Tamamlama hattında yüzeyinde gözle görülür şekilde hata olmayan malzemelerin sürekli hata varmış gibi kenara ayrılması üzerine bu sorun çalışanlarla yapılan toplantıda dile getirilmiştir. Bunun üzerine $8 \mathrm{D}$ uygulaması ile problem tespiti ve kalıcı çözüm üretmek konusunda araştırma yapılmasına karar verilmiştir. İzlenen aşamalar şu şekilde özetlenebilir:

1. Adım-Konunun Seçimi: Yüzey hata kontrolü yapan cihazın, üzerinde problem olmayan malzemeleri kenara ayırması üzerine buna neden olabilecek durumların incelenmesi kararı alınmıştır.

2. Adım-Mevcut Durum Analizi: Tamamlama hattında yüzey hata kontrolü yapan cihazdan geçen malzemelerin yüzeyinde sürekli hata çıkmaktaydı. Malzemelerde hata olmamasına rağmen cihaz problem varmış gibi sinyaller gönderip mamülü kenara ayırıyordu. Malzemeler operatör tarafından gözle kontrol edilince hata olmadığı fark ediliyordu. Aynı malzemeler makineden bir daha geçirilince problemin devam ettiği görüldü. Bu durum hata barındırmayan malzemelerin ikinci kaliteye ayrılmasına ve hattın sürekli durmasına neden olmaktaydı. Hem zaman kaybına hem de israfa sebep olarak verimsizliği tetiklemekteydi. Bunun üzerine bu hatanın ana sebebini bulmak ve ortadan kaldırmak amacıyla konuyla ilgili kişilerden ekip oluşturuldu.

3. Adım-Hedef: Ana hedef problemin esas sebebini bularak tamamen ortadan kaldırmak ve tekrarının olmaması için düzenleyici-önleyici aksiyonlar belirlemek ve yaşanan duruşları yok etmektir. Müşteri için ilk etapta sorun teşkil edecek bir durum bulunmamaktadır. Çünkü malzeme, hem iç hem de yüzey kontrolünden geçmektedir. Cihazın yüzeyde hata bulup o bölgeyi kırmızıya işaretlemesi üzerine operatörler, kontrol ettiğinde sorun olmadığı görülmektedir. Fakat malzemeler her ihtimale karşı makineden bir kez daha geçirilmektedir.

4. Adım-Kök Neden Analizi: Bu aşamada probleme neden olabilecek konular, kurulan ekip ile Şekil 7'de görüldüğü gibi balık kılçı̆̆ı diyagramı kullanılarak tespit edilmeye çalışılmıştır. Hatanın ortaya çıkmasına sebep olabilecek konular şu şekilde sıralanmıştır:

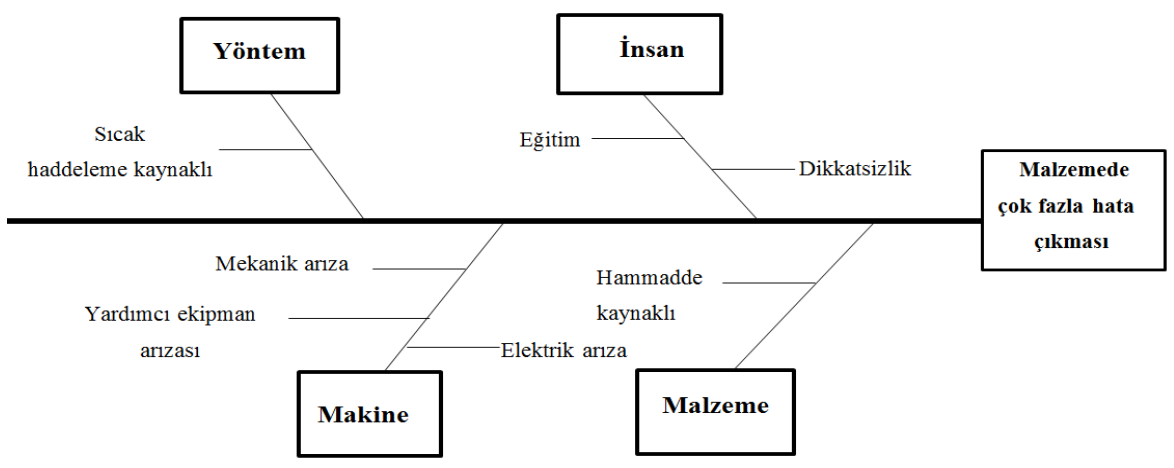

Şekil 7: Probleme İlişkin Nedenlerin Analizi

İnsan faktörü: Hatanın çalışan kaynaklı olabileceği düşünüldü. Eğitim eksikliği, dikkatsizlik gibi durumlardan kaynaklı makinenin kalibrasyon ayarlarının eksik yapılması nedeniyle cihazın yanlış ölçebileceği öngörüldü.

Yöntem faktörü: Tamamlama hattına gelecek olan malzemelerin yarı mamulünün üretildiği sıcak haddeleme hattındaki işlemler sırasında yüzeyi hatalı malzemelerin üretilmesi bu duruma sebep olabileceği düşünüldü. 
Malzeme faktörü: Tedarikçiden temin edilen kütük olarak adlandırılan hammaddelerden kaynaklı hatalar bu duruma sebep olabileceği belirtildi.

Makine faktörü: Mekanik, elektriksel ve yardımcı ekipmanlara ilişkin arıza sebebi ile cihazın yanlış ölçümler yapabileceği göz önünde bulunduruldu.

Belirtilen sebeplerin araştırılması için her bir konu başlığı ekip üyelerine paylaştırıldı. İnsan faktörü incelendiğinde, eğitimlerin verildiği ve ayarlamalarda sorun olmadığı tespit edildi. Yöntem faktörü için sıcak haddede üretilen yarı mamuller için kontroller yapıldı. Malzemelerde hata olmadığı kalite tarafından onaylandı. Malzeme faktörü de irdelendi ve tedarikçi kaynaklı bir problem olmadığı anlaşıldı. Bunun üzerine hattın durdurulmasına ve makinenin sökülerek incelemeler yapılmasına karar verildi.

Makinede yapılan incelemeler neticesinde sorunun, yardımcı ekipman olarak kullanılan kömürlerin aşınması nedeniyle ortaya çıktığı tespit edilmiştir. Sinyalin ulaşmadığı ve hatalı olarak algılandığı görülmüştür. Yüzey kontrolü yapan cihazın probları, malzeme ilerlerken malzemenin üzerinde saniyede 25 tur dönerek (üretim hızı ve ebatına göre değişken bir hızdır) kontrol yapmaktadır. Makinenin döner kısmına elektrik enerjisi ve prob sinyalleri, döner bir sinyal iletim bileziği üzerinden ulaşmaktadır. Bu bileziğin dönen hareketli tarafında bakır 5 adet izole halka bulunmaktadır. Makinenin sabit kısmında ise her halkaya 4 adet kömür bağlanması suretiyle 5 adet sinyali hareketli kısma aktarmaktadır. Bunun için toplam 20 adet kömür takılıdır. Sürtünme dolayısı ile makinanın çalışma süresiyle doğru orantılı olarak kömürler aşınmaktadır. Hareketli halkaların arkasında eksik elektrik bağlantıları şüphesi üzerine kablo bağlantıları çözülüp bir takım incelemeler yapılması neticesinde makine üzerindeki bakır bileziğin 5 yolundan ikisinin kullanılmadığı ve sinyal gitmediği anlaşılmıştır. Bu sebeple 2 yol üzerindeki 8 adet kömürün gereksiz yere kullanılması söz konusudur.

Makinenin kullanımına ilişkin dokümanlar incelenerek dokümanlarda 20 adet kömürün gösterildiği tespit edilmiştir. Cihazın Almanya'daki süpervizörüne durum anlatılmıştır. Bunun neticesinde makinenin ilk tasarımında kullanılması planlanan kömürlerin ve yolların daha sonra tasarımdan çıkarıldığı fakat bunun dokümanlarda ve ilk devreye alma sırasında fark edilmediği tespit edilmiştir.

5. Adım-Proje Planı: Makinadan 8 adet kömür çıkarılarak hem kömür tasarrufu yapılması hem de bakır bilezikte iki adet yol kullanılmayarak ömrünün uzatılması söz konusu olmuştur. Bu sayede yıllık 8400 TL tasarruf yapılması öngörülmektedir.

6. Adım-İyileştirme Çalışmaları: Kullanılan kömür sayısı azaltılarak bakır bileziğin ömrü uzatılmıştır. Kömür değişim adetleri ve değiştirildiği tarihler sisteme kayıt edilerek yedekleme planı yapılmıştır.

7. Adım-Sonuçların Doğrulanması: Makinenin yeni haliyle çalışması test edilmiştir.

8. Adım-Standartlaş̧ırma ve Yaygınlaştırma: $\mathrm{Bu}$ sorunun kaynağı, imalatçının dokümanlarında hata yapması, devreye alma sırasında süpervizörün dikkatli olmaması ve daha sonra konunun irdelenmemiş olmasıdır. Düzenlenmiş yeni çalışma sistemi ile hatalardan arındırılmış ve gereksiz duruşların ortadan kalktığı bir yapıya kavuşulmuştur.

\subsection{HTEA Uygulamasi}

İşletmenin ana müşterilerinden birinin sürekli sipariş verdiği ürün grubu için HTEA uygulaması gerçekleştirilmiştir. Geçmiş veriler incelenerek temel problemler sıralanmıştır. İmalatta görevli kişilerden bir ekip oluşturularak, beyin firtınası metodu kapsamında her problem için şiddet, olasılık ve saptanabilirlik değerleri belirlenmiştir. Öncelikle imal edilen ürünün izlediği süreçler ifade edilmiştir. Sırasıyla şu şekilde özetlenebilir: 
Hammadde kabulü: Kullanılan hammaddeler kütük olarak adlandırılmaktadır. Tedarikçiden gelen $12 \mathrm{~m}$ kütüklerin kabulü yapılarak hammadde alanına alınmaktadır.

Kütük kesim işlemi: Üretime aktarılacak kütükler kesilmektedir.

Kesilen kütüklerin istiflenmesi: Üretim çizelgesine göre istifleme yapılmaktadır.

Tav firını: İstiflenen kütükler sırasıyla belli bir sıcaklığa ulaşana kadar fırın içinde ssıtılmaktadır. Bu sayede haddeleme sırasında şekillendirme için gerekli olan enerji azalmakta ve şekillendirme kolaylığı sağlanmaktadır.

Tufal alma: Fırından çıkan malzemeler yüksek sıcaklıkta oksijen ile birleşme eğilimi göstererek oksitlenmektedir. Malzemenin yüzey özelliklerini bozan oksit tabakasından arındırılması amacıyla tav firınından çıkan malzemeye basınçlı su ile tufal temizleme işlemi yapılmaktadır. yapılmaktadır.

Hazırlama (ön şekillendirme): Müşterinin istediği çap dikkate alınarak hazırlama işlemi

Sürekli haddeleme işlemi: Malzemenin, belirli bir sıralama mantığıyla düzenlenen ve kalibreleri açılan dikey/yatay hadde tezgâhlarından geçmesiyle son kesitine ve izgara boyutuna ulaştığı bölümdür. Lazer sistemi ile malzemenin anlık boyut ölçümü yapılarak hassas çalışma sağlanır. Müşterin istediği ebata göre tezgah sayısı değiştirilebilmektedir.

Soğutma 1zgarası: Haddeleme işleminden sonra, boyları uzayan malzemeler müşterinin istediği boyda kesilmeden önce bu izgarada soğutma işlemi gerçekleştirilir. Bu aşamada kontrollü soğutma yapılarak malzemenin sertleşmesi sağlanır. Aksi takdirde malzemeler istenilen formda kesilemez.

Makas: Haddeleme işleminden sonra boyları uzayan malzemelerin müşterinin istediği boya kesildiği aşamadır.

Son kalite kontrol: Kesilen malzemelerden üretim aşamasında numune alınarak kontrollerinin yapılmasıdır.

Paketleme: Üretimi tamamlanan malzemelerin müşterinin varsa özel talebine göre yoksa $2500 \mathrm{~kg}$ olarak paketlemesinin yapılmasıdır.

Tartım-barkod-boyama: Paketler kantar üzerinde ağırlıkları ölçülerek sisteme girilir. Varsa müşteri talebine göre malzemenin uçları boyanır yoksa önceden belirlenen kalite standardına göre boyama yapılır.

Tamamlama hattı: Malzemeler müşteri taleplerine göre iç hata ve/veya yüzey çatlak kontrolünden geçirilir. Yüzey çatlak kontrolü için "Eddy-Current" ve "manyetik parçacıkla muayene" yöntemlerinin birleşimi ve "manyetik akı kaçağı" yöntemi, iç hata kontrolü için ise "ultrasonik test" uygulanmaktadır. yap1lır.

Kalite kontrol: Tamamlama hattından geçen malzemeler için tekrar kontrol işlemi

Taşıma ve yerleştirme: Malzemeler müşteriye sevk edilene kadar depo alanına alınır.

Sevkiyat: Malzemenin gerekli belgeler ile müşteriye sevk edilme aşamasıdır. 
Tablo 3: Hata Türleri ve RöS Değerleri

\begin{tabular}{|c|c|c|c|c|c|c|c|c|}
\hline $\begin{array}{l}\text { Hata } \\
\text { Türü } \\
\text { No }\end{array}$ & Hata Türleri & $\begin{array}{l}\text { Hatanın Olası } \\
\text { Etkileri }\end{array}$ & $\frac{\ddot{c}}{\stackrel{0}{0}}$ & Hata Sebepleri & 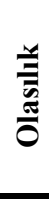 & Kontrol & 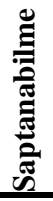 & $: \stackrel{\mathscr{C}}{\varrho}$ \\
\hline 1 & $\begin{array}{l}\text { Yanlış kompozisyonda } \\
\text { malzeme kullanımı }\end{array}$ & $\begin{array}{l}\text {-Uygun olmayan } \\
\text { malzemelerin seçimi }\end{array}$ & 8 & $\begin{array}{l}\text { - Hatalı mal kabul } \\
\text { - Etiket yapıştırma } \\
\text { hatası }\end{array}$ & 3 & $\begin{array}{l}\text {-Tedarikçi kalite } \\
\text { belgesi kontrol }\end{array}$ & 7 & 168 \\
\hline 2 & $\begin{array}{l}\text { Etiketin yanlış olması } \\
\text { (Doküm no, kalite, } \\
\text { vb.) }\end{array}$ & $\begin{array}{l}\text { - Kalite özelliklerinin } \\
\text { karışması }\end{array}$ & 8 & $\begin{array}{l}\text { - Tedarikçi kaynaklı } \\
\text { - çalışan kaynaklı }\end{array}$ & 3 & -Görsel kontrol & 7 & 168 \\
\hline 3 & $\begin{array}{l}\text { Barkot okutamama } \\
\text { (adet, etiket } \\
\text { bilgilerinin yanlış } \\
\text { verilmesi) }\end{array}$ & $\begin{array}{l}\text { - Kalite veya döküm } \\
\text { karışması } \\
\text { - İzlenebilirliğin ve } \\
\text { raporlanmanın } \\
\text { sağlanamaması } \\
\text { - Hammadde stoğunun } \\
\text { sistemsel olarak takip } \\
\text { edilememesi }\end{array}$ & 8 & $\begin{array}{l}\text { - Barkod düşmesi } \\
\text { - Barkodun olmaması } \\
\text { - Barkod okutma } \\
\text { cihazının arızalı olması } \\
\text { - İş emrine hatalı } \\
\text { hammadde } \\
\text { tanımlanması. } \\
\text { - Çalışan kaynaklı } \\
\text { hatalar }\end{array}$ & 5 & $\begin{array}{l}\text {-Hatalı barkod } \\
\text { olduğu zaman siren } \\
\text { sisteminin devreye } \\
\text { girmesi } \\
\text {-RF cihazlarının } \\
\text { hatalı barkodu } \\
\text { okumaması }\end{array}$ & 3 & 120 \\
\hline 4 & $\begin{array}{l}\text { Sisteme eksik kütük } \\
\text { girilmesi }\end{array}$ & $\begin{array}{l}\text { - Siparişin eksik kalması } \\
\text { (Miktar hatası) }\end{array}$ & 5 & $\begin{array}{l}\text { - Sipariş hatası. } \\
\text { - Tedarikçi kaynaklı } \\
\text { miktar veya termin } \\
\text { problemi } \\
\text { - Planlama kaynaklı } \\
\text { (üretim prog. geç } \\
\text { yayınlanması) } \\
\text { - Kesim hızının üretim } \\
\text { hızına ulaşamaması } \\
\text { - Satın alma kaynaklı } \\
\text { olarak oksijen tüpünün } \\
\text { olmaması }\end{array}$ & 3 & $\begin{array}{l}\text {-Üretim programına } \\
\text { göre görsel kontrol }\end{array}$ & 7 & 105 \\
\hline 6 & $\begin{array}{l}\text { Yanlış malzeme } \\
\text { gönderilmesi }\end{array}$ & $\begin{array}{l}\text {-Müşteri } \\
\text { memnuniyetsizliği }\end{array}$ & 8 & $\begin{array}{l}\text {-Personel kaynaklı } \\
\text {-Etiketleme, Boyama } \\
\text { Hataları } \\
\text {-Taşeron kaynaklı hata }\end{array}$ & 2 & $\begin{array}{l}\text {-Sevk aşamasında; } \\
\text { Etiket ve renk } \\
\text { kontrolü } \\
\text {-Çap kontrolü } \\
\text {-Boy kontrolü } \\
\text {-Yüzey kontrolü }\end{array}$ & 5 & 80 \\
\hline
\end{tabular}

Bahsedilen tüm alt süreçlerde karşılaşılan hata türleri 62 adet olarak belirlenmiştir. $\mathrm{Bu}$ çalışmada ise sayfa kısıtı nedeniyle 6 adet hata türü ile ilgili açıklamalara yer verilmiştir. Tablo 3 'te hata türleri ve olası etkileri özetlenmiştir. Şiddet, olasılık ve saptanabilme değerleri ifade edilerek, hesaplanan RÖS değerleri sunulmuştur.

Tablo 4'teki her hata türü için belirlenen aksiyonlar ifade edilmiştir. Her biri için sorumlu atanmıştır. Gerçekleşmiş aksiyonlar için yeni şiddet, olasılık ve saptanabilirlik değerleri tespit edilerek RÖS değeri hesaplanmıştır. Planlanan aksiyonlar için ise tarihler belirlenmiştir. $\mathrm{Bu}$ iyileştirme çalışması sayesinde hammadde temininden nihai ürünün müşteriye ulaşana kadar olan aşamalarda tüm hatlarda yaşanabilecek olası hatalar, onların etkileri alt süreçlere kadar indirgenmiş olup değerlendirilmiştir. Hatanın oluşması neticesinde öncelikle RÖS değeri yüksek olan sebepler için, devamında ise tüm hata türleri için iyileştirmeler planlanmıştır. İlerleyen aşamalarda da HTEA analizinin belirli aralıklarla tekrarlanması gereklidir. Mevcut yapının analizinin yanı sıra yeni oluşabilecek hata türlerinin de irdelenmesi gereklidir. 
Tablo 4: Hata Türleri Kapsamındaki Aksiyonlar

\begin{tabular}{|c|c|c|c|c|c|c|c|c|}
\hline \multirow[b]{2}{*}{$\begin{array}{c}\text { Hata } \\
\text { Türü } \\
\text { No }\end{array}$} & \multirow[b]{2}{*}{$\begin{array}{l}\text { Hata } \\
\text { Türleri }\end{array}$} & \multirow[b]{2}{*}{ Aksiyon } & \multirow[b]{2}{*}{ Tarih } & \multicolumn{5}{|c|}{ Aksiyon Sonucu } \\
\hline & & & & $\begin{array}{l}\text { Gerçekleşme } \\
\text { Durumu }\end{array}$ & $\frac{\overline{0}}{\frac{0}{2}}$ & 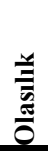 & 㐫 & 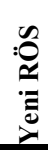 \\
\hline 1 & $\begin{array}{l}\text { Yanlış } \\
\text { kompozisyonda } \\
\text { malzeme } \\
\text { kullanımı }\end{array}$ & Yeni kütük kontrol sisteminin devreye alınması & Ok & $100 \%$ & 8 & 3 & 3 & 72 \\
\hline 2 & $\begin{array}{l}\text { Etiketin yanlıs } \\
\text { olmas1 (Doküm } \\
\text { no, kalite vb.) }\end{array}$ & $\begin{array}{l}\text { Yeni kütük kesim otomasyonu ile yeni istif } \\
\text { düzenine geçilmesi }\end{array}$ & $\begin{array}{l}\text { Aralık } \\
2016\end{array}$ & - & - & - & - & \\
\hline 3 & $\begin{array}{l}\text { Barkot } \\
\text { okutamama } \\
\text { (adet, etiket } \\
\text { bilgilerinin } \\
\text { yanlış } \\
\text { verilmesi) }\end{array}$ & $\begin{array}{l}\text { Barkod okuma sisteminin Fırın Giriş Kapağı ile } \\
\text { otomasyon olarak entegrasyonu }\end{array}$ & Ok & $100 \%$ & 8 & 4 & 2 & 64 \\
\hline 4 & $\begin{array}{l}\text { Sisteme eksik } \\
\text { kütük girilmesi }\end{array}$ & $\begin{array}{l}\text { İş emirlerine ait kütüklerin tanımlanması } \\
\text { işleminde iş emri bazlı tanımlama yapılması }\end{array}$ & Ok & $100 \%$ & 5 & 3 & 5 & 75 \\
\hline 5 & $\begin{array}{l}\text { Haddelemede } \\
\text { kat oluşumu }\end{array}$ & Hazırlama aşamasında uygulama değişikliği & Ok & $100 \%$ & 7 & 3 & 2 & 42 \\
\hline 6 & $\begin{array}{l}\text { Yanlış } \\
\text { malzeme } \\
\text { gönderilmesi }\end{array}$ & Alın etiketi uygulaması & $\begin{array}{l}\text { Şubat } \\
2017\end{array}$ & - & - & - & - & - \\
\hline
\end{tabular}

\section{SONUÇ}

Süreç yönetimi; müşteri beklentilerini karşılamak amacıyla girdileri çıktılara dönüştüren faaliyetlerin izlenmesi, kontrol edilmesi, gerekli durumlarda ilgili bölümlerde iyileştirmelerin yapılarak önlemlerin alınmasıdır. Süreç yönetimi yaklaşımı ile tüm süreçler yakından takip edilerek maliyet, israf ve zaman kaybına sebep olan katma değer sağlamayan faaliyetler sistemden uzaklaştırılarak kaliteli çıktılar elde edilebilmektedir. Bu yönetim yaklaşımı şirketlerin kendilerini daha iyi tanımalarına, disiplinler arası etkileşim ve iletişimin artmasına olanak sağlamaktadır.

İyileştirmelerin planlanabilmesi için, süreçlerin doğru tanımlanması ve iyi analiz edilmesi gereklidir. Yapılacak girişimlerden sonra ise sürekli iyileştirme felsefesi ile daha iyi yönetilmeye odaklanılmalıdır. Bu iyileştirmeler çok büyük yatırımlar gerektirmeden atılan küçük adımlar da olabilir. Önemli olan işleyişi periyodik olarak takip etmek ve olası hataları öngörüp bunlar için önlemler almaktır. Bu noktada üst ve orta kademe yöneticilere büyük görevler düşmektedir. Tüm çalışanlarına sürekli iyileştirme anlayışını benimsetmeleri gerekir. Bunun için çalışanlara teorik ve uygulamalı eğitimler verilmeli, ayrıca üst yönetim desteği hissettirilmelidir.

$\mathrm{Bu}$ makale, devam eden bir çalışmanın mevcut çıktılarını açıklamaktadır. Başlangıç aşamasında yapılan iyileştirmeler dahi önemli sonuçlar ortaya çıkarmıştır. Maliyet tasarrufu, zaman tasarrufu, daha hızlı ve hatasız iş yapabilme gibi kazanımların bu safhada elde edilmesi, daha büyük iyileştirmeler için motivasyonu arttırarak zemin hazırlanmasını sağlamıştır. İlerleyen çalışmalarda sadece imalat kısmı değil, tedarik ve dağıtım aşamalarını da içeren, tedarik zinciri kapsamındaki iyileştirmeler hayata geçirilebilir. 


\section{KAYNAKÇA}

Arslan, H. M., Yıldız, M. S. ve Uysal, H. T. (2015). Kesim hattında süreç iyileştirme ve etkin tasarruf: Ağaç işleri atölyesine yönelik bir uygulama. Journal of World of Turks, 7(1), 121-136.

Bozdemir, E. ve Orhan, M. S. (2011). Üretim maliyetlerinin düşürülmesinde kaizen maliyetleme rolü ve uygulanabilirliğine yönelik bir araştırma. Atatürk Üniversitesi Sosyal Bilimler Enstitüsü Dergisi, 15(2), 463-480.

Bulut, S. (2012). Beyaz eşya yan sanayi sektöründe erp ve yalın üretim olgunluğu analizi ve otomotiv yan sanayi ile kıyaslama. İstanbul Teknik Ünversitesi, Fen Bilimleri Enstitüsü, Endüstri Mühendisliği Anabilim Dall, Mühendislik Yönetimi Programı, Yüksek Lisans Tezi. İstanbul.

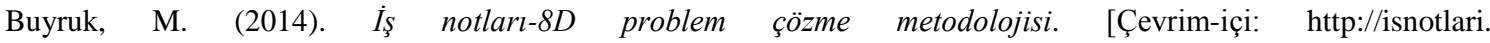
blogspot.com.tr/2014/03/8d-problem-cozme-metodolojisi.html], Erişim tarihi: 07.11.2016.

Çetinay, H. (2016). Kaizen, Yayın No:3, İstanbul: Kaizen Atölyesi Yayınları.

Chiozza, M. L., \& Ponzetti, C. (2009). FMEA: a model for reducing medical errors. Clinica Chimica Acta, 404 (1), 75-78.

Eleren, A. (2007). Eğitim başarısının artırılmasında süreç geliştirme yöntemlerinin kullanılması ve bir uygulama, Afyon Kocatepe Üniversitesi IIBF Dergisi, 9(2), 1-25.

Ertuğrul, İ. (2006). Toplam Kalite Kontrol. Bursa: Ekin Kitapevi.

Feili, H. R., Akar, N., Lotfizadeh, H., Bairampour, M., \& Nasiri, S. (2013). Risk analysis of geothermal power plants using Failure Modes and Effects Analysis (FMEA) technique. Energy Conversion and Management, 72, 69-76.

İnce, A. R., Erol, Y., \& Karagöz , N. (2013). Bir süreç iyileştirme örneği olarak görüntü arşivleme ve iletişim sisteminin (Pacs) değerlendirilmesi (Sivas Numune Hastanesi Uygulaması). İsletme Araştırmaları Dergisi, 243-257.

Gitlow, H. S., Oppenheim, A. J., Oppenheim, R. \& Levine, D. M. (2005), Quality management, New York, McGraw Hill-Third Edition.

Grace, D. D. (2016). ASQ-Eight diciplines (8D). [Çevrim-içi: http://asq.org/learn-about-quality/eight-disciplines-8d/], Erişism tarihi: 24.09 .2016

Işı̆̆ıçok, E. (2012). Toplam kalite yönetimi bakış açısıyla istatistiksel kalite kontrol, Bursa: Ezgi Kitabevi.

Kahraman, Ö. ve Demirer, A. (2010). OHSAS 18001 Kapsamında FMEA Uygulaması. Makine Teknolojileri Elektronik Dergisi, 7(1), 53-68.

Kang, J., Sun, L., Sun, H., \& Wu, C. (2017). Risk assessment of floating offshore wind turbine based on correlationFMEA. Ocean Engineering, 129, 382-388.

Kumru, M. \& Kumru, P. Y. (2010). Hastanelerde satın alma sürecinin iyileştirilmesi: Bir örnek uygulama, II. Uluslararası Sağlıkta Performans ve Kalite Kongresi Bildiriler Kitabı, 171- 183.

Oğuz, A. M. (2011). Süreç yönetimi ve bir gayrimenkul değerlenirme tekniği uygulaması: Vakıflar genel müdürlüğü örneği. İstanbul Teknik Üniveristesi, Fen Bilimleri Enstitüsü, Gayrimenkul Geliştirme Anabilim Dall, Gayrimenkul Geliştirme Programı, Yüksek Lisans Tezi. İstanbul.

Ookalkar, A. D., Joshi, A. G., \& Ookalkar, D. S. (2009). Quality improvement in haemodialysis process using FMEA. International Journal of Quality \& Reliability Management, 26(8), 817-830.

Özçelik, T. Ö. \& Cinoğlu, F. (2013). Yalın felsefe ve bir otomotiv yan sanayi uygulaması. İstanbul Ticaret Üniversitesi Fen Bilimleri Dergisi, 12(23), 79-101.

Özdağoğlu, A., \& Rebiş, S. (2016). Applications of Kaizen And Cycle Time Reduction as Lean Production Techniques in a Semi-Flexible PVC Film Producer. Uluslararası Yönetim Íktisat ve İşletme Dergisi, 12(28), 25-37.

Öztürk, A. (2016), Kaizen, Yayın No:4, İstanbul: Kaizen Atölyesi Yayınları.

Pekin, E. ve Çil, İ. (2014). Kauçuk sektörü poke yoke uygulaması. SAÜ Fen Bilimleri Dergisi, 19 (2), 163-170.

Pillay, A. \& Wang, J., (2003), Modified failure mode and effects analysis using approximate reasoning, Reliability Enginering and System Safety, 79(1), 69-85.

Saurin, T. A., Ribeiro, J. L. D., \& Vidor, G. (2012). A framework for assessing poka-yoke devices. Journal of Manufacturing Systems, 31(3), 358-366. 
Sawhney, R., Subburaman, K., Sonntag, C., Rao Venkateswara Rao, P. \& Capizzi, C. (2010). A modified FMEA approach to enhance reliability of lean systems. International Journal of Quality \& Reliability Management, 27(7), 832-855.

Solak, E. ve Korkut, D. S. (2015). Örnek bir işletmede gerçekleştirilen kalite kontrol uygulamalari, [Çevrim-içi: http://sutod.selcuk.edu.tr/sutod/article/viewFile/221/171 /], Erişim tarihi: 11.06.2016.

Treurnicht, N. F., Blanckenberg, M. M. \& Van Niekerk, H. G. (2011). Using poka-yoke methods to 1mprove employment potential of intellectually disabled workers. The South African Journal of Industrial Engineering, 22(1), 213-214.

Tuzkaya, U. R. ve Aksu, İ. (2013). Üretimde ara stok yönetim süreçlerinin iyileştirilmesi ve bir uygulama. Beykoz Akademi Dergisi, 1(2), 44-75.

Y1lmazer, A. (2016). Kalite kontrol ve kalite güvence, [Çevrim-içi: http://aliyilmazer.blogspot.com.tr/2016/03/8dproblem-cozme-yontemi-nedir.html], Erişim tarihi: 11.06.2016.

Yücel, Ö. (2007), Konfeksiyon üretiminde hata türü ve etkileri analizi, Tekstil ve Konfeksiyon, 17(2), 126-131.

Yüksel, H. (2010). Üretim/Işslemler yönetimi, Nobel Yayın Dağıtım, Ankara.

Zerenler, M. ve Karaboğa, K. (2014). Müşteri memnuniyetinin sağlanmasında hataların önlenmesine yönelik üretim odaklı bir bakış açısı: Poka-Yoke sistemleri. Selçuk Üniversitesi Sosyal Bilimler Enstitüsü Dergisi, Özel Sayı, 263275 . 